\title{
CURATIVE POTENTIAL OF QUERCETIN AGAINST CARBON TETRA CHLORIDE- INDUCED HEPATOTOXICITY IN WISTAR RATS
}

\author{
S. Mushtaq and L. Naz \\ Department of Physiology, University of Karachi, Pakistan \\ Corresponding Author Email: samtaq.physio@gmail.com
}

\begin{abstract}
Several studies have revealed that extensive metabolic involvement of liver has rendered the liver susceptible against the xenobiotics' devastating effects. Serving as the most potent oxidative stress mediated hepatotoxic agent via reductive CYP2E1 mediated activation, $\mathrm{CCl}_{4}$ leads to trichloromethyl-radical $\left(\mathrm{CCl}_{3}^{-}\right)$and trichloromethyl peroxy $\left(\mathrm{CCl}_{3} \mathrm{OO}^{-}\right)$ radicals' production with subsequent hepatocyte-damage progression. The present investigation was therefore, aimed to investigate the potential of a dietary flavonol, Quercetin against $\mathrm{CCl}_{4}$ induced chronic hepatotoxicity. 60-days experimental protocol was conducted using 24 male Wistar rats. Animals were divided into four groups. I; Control, II; (CCl ${ }_{4}$-treated) received $0.8 \mathrm{ml} / \mathrm{kg} \mathrm{BW}$ twice weekly, III; $\left(\mathrm{CCl}_{4}+\right.$ Quercetin treated) received $\mathrm{CCl}_{4}, 0.8 \mathrm{ml} / \mathrm{kg} \mathrm{BW}$ twice weekly and $1 \mathrm{ml} / \mathrm{kg}$ quercetin extract (daily, p.o.) and IV; (Quercetin treated) received $1 \mathrm{ml} / \mathrm{kg}$ quercetin extract (daily, p.o.). Aspartate Aminotransferase, Alanine aminotransferase, Alkaline Phosphatase, Bilirubin, Malondialdehyde were assessed. Antioxidant evaluation (Superoxide Dismutase, Glutathione, and Catalase) and hepatic histopathological investigation was done. The ALT, AST and Bilirubin levels were significantly reduced in the $\mathrm{CCl}_{4}+$ Quercetin-treated group as compared to the $\mathrm{CCl}_{4}$-treated group. Significant elevation was observed in the $\mathrm{SOD}$, GSH and Catalase levels in the $\mathrm{CCl}_{4}+$ Quercetin-treated group as compared to the $\mathrm{CCl}_{4}$-treated group. Quercetin administration with $\mathrm{CCl}_{4}$ resulted in reversal of the hepatotoxicity features through reduction in the elevated-enzymes level, lipid peroxidation as well as through raising the decreased antioxidant levels to near normal.
\end{abstract}

Keywords: Quercetin, $\mathrm{CCl}_{4}$, hepatotoxicity.

https://doi.org/10.36899/JAPS.2020.6.0162

Published online August 03,2020

\section{INTRODUCTION}

Liver being one of the vital organs in humans, plays the most significant role in storage, enzymatic metabolism, secretion, detoxification and elimination of drugs and xenobiotics, which has made liver more susceptible for the detrimental effects produced by the xenobiotics (Bedi et al., 2016). Cellular degeneration, inflammatory responses along with fibrotic alterations contribute to hepatic functional decline as evident in cirrhotic liver. Instability of reactive free radicalsmediated oxidative stress has found to be the major mechanism in causing hepatotoxicity. Prevalence of cirrhosis has always been under-estimated in European countries due to difficulties in accessing data from individual countries (Blachier et al., 2013), yet findings proposed approximately $1,70,000$ deaths per annum (0.1\% mortality rate) in Europe (Zatoński et al., 2010). In Pakistan, Hepatitis C Virus, Hepatitis B Virus or both coexist with cirrhosis in $73 \%$ of patients; furthermore, $\mathrm{HCV}$ sero-prevalence in $60 \%$ of cirrhotic patients were also documented in Karachi (Umer and Iqbal, 2016).

Widespread use of Carbon Tetrachloride $\left(\mathrm{CCl}_{4}\right)$ as organic solvent in insecticides, resin, wax, oil products, rubber products, cooling equipment, dry cleaning agents and as furniture and carpet stain remover, has made it a great concern as a frequent environmental toxin (Altuğ et al., 2007). Owing to the hepatotoxicityproducing properties of carbon tetra chloride, its widespread use is done by many researchers for in-vivo and in-vitro toxicity model development (CoballaseUrrutia et al., 2013; Khuon, 2012; Salem et al., 2015; Jaramillo-Juarez et al., 2008; Ogeturk et al., 2005). Thus, $\mathrm{CCl}_{4}$ administration specifically affects hepatocytes causing cellular necrosis, fatty deterioration, fibrotic changes, and Cirrhosis.

Quercetin (QC) is one of the abundantly found dietary phytochemicals (Prior, 2003) especially in tea, fruits and vegetables (Terao et al., 2008; Kelly, 2011). Onions (Allium Cepa L.) are found to be the richest among other QC containing vegetables (i.e. 200-600 $\mathrm{mg} / \mathrm{kg}$ ) (Hertog et al., 1993), whereas other potentially high amounts of QC were quantified in asparagus, green pepper, and red leaf lettuce (Nishimuro et al., 2015), tomatoes broccoli, apple, lettuce (Uzun et al., 2010; Nishimuro et al., 2015). Several studies have suggested protective role of QC through its antioxidative, antiinflammatory (Hassan et al., 2019; Al-Harbi, 2019; Afifi et al., 2018), chemo preventive (Russo et al., 2014), antiviral, anti-ischemic, and anti-allergenic potential in diversified life-style related diseases (Morales et al., 2012; Nishimuro et al., 2015). 
To the best of our knowledge, data regarding the hepatoprotective effects of QC is scarce. The intended purpose of the current investigation was therefore aimed to construct an experimental rat model of chronic liver disease (liver cirrhosis) through repeated doses of $\mathrm{CCl}_{4}$ and to investigate the potential of $\mathrm{QC}$ against $\mathrm{CCl}_{4}$ induced chronic hepatotoxicity.

\section{MATERIALS AND METHODS}

Animal Selection and Acclimatization: Male Wistar rats $(n=24)$, obtained from Dow University of Health Sciences, Karachi, Pakistan, were weighed and housed in clean, dry, propylene cages. The animals were exposed to 12 hours dark and light cycle at controlled temperature $\left(25 \pm 2^{\circ} \mathrm{C}\right)$. The rats were provided with standard lab diet and water was provided ad libitum. Acclimatization was done for one week prior to start of the experiment. The animals were maintained as per the guidelines and regulations of the local animals' ethical committee of the University of Karachi.

QC Extraction: QC was extracted via lyophilized onion and onion skin with methanol using Waring blender (5 minutes) and filtered via Whatman no. 1 filter paper. Concentrated filtrate was obtained via rotary evaporation (Velioglu and Mazza, 1999; Shin et al.,2010).

Experimental groups: The animals were randomly divided into four experimental groups $(n=6)$.

Group I: Control group; given normal saline $(2 \mathrm{ml} / \mathrm{kg}$ of BW); Group II: $\mathrm{CCl}_{4}$ treated group; $\mathrm{CCl}_{4}(0.8 \mathrm{ml} / \mathrm{kg}$ BW.) administered subcutaneously, twice a week; Group III: $\mathrm{CCl}_{4}+\mathrm{QC}$ treated Group; received $\mathrm{CCl}_{4}$ via subcutaneous injection $(0.8 \mathrm{ml} / \mathrm{kg} \mathrm{BW})$ and $1 \mathrm{ml} \mathrm{QC}$ extract/100g BW p.o. daily; Group IV: QC treated Group; received $1 \mathrm{ml}$ quercetin extract/100g BW p.o. daily.

Following 60 days of treatment, the animals were sacrificed, hepatic tissues were excised, washed with saline, weighed and stored at $-80^{\circ} \mathrm{C}$. Plasma and serum samples were collected via heparinized tubes and serum separating tubes, respectively and stored at $-80^{\circ} \mathrm{C}$ for biochemical estimations.

Blood Collection and Processing: Blood was collected from each experimental group animal after 48 hours of the last dose via decapitation according to the standard protocol and then transferred in heparinized sample tubes and serum separating tubes. Plasma and serum thus obtained was stored at $-80{ }^{\circ} \mathrm{C}$ until analysis was done.

Liver sample Preparation of Liver Homogenate: Liver lobes were made free of the associated fascia, followed by saline rinsing, drying then $10 \%$ Formalin immersion for histopathological specimen's preparation and consequent storage at $-80^{\circ} \mathrm{C}$ for further analytical estimations. Liver parenchymal-lysate was made via tissue perfusion with saline in chilled $(1.17 \%)$ potassium chloride using homogenizer, the resultant homogenate thus procured was subjected to centrifugation $(8000 \mathrm{~g}, 5$ minutes, $4^{\circ} \mathrm{C}$ ) for nuclear-fragments' isolation. Postmitochondrial supernatant (PMS) was obtained by centrifuging the post-nuclear supernatant (10500g, 20 minutes, $4^{\circ} \mathrm{C}$ ). Hepatic antioxidants and Malondialdehyde estimation were done using the homogenate.

Histopathological Examination: The hepatic tissues were fixed in 10\% formalin and paraffin embedded. $4 \mu \mathrm{m}$ thick sections were then made and staining with Hematoxylin and Eosin was done for microscopical examination. The Hepatic-lesion's extent was evaluated from the histological sections via grading and quantitative scores (French et al., 1988). The grading system is as follows:

\begin{tabular}{ll}
\hline Scores & Interpretation \\
\hline Score 0 & no conspicuous impairment \\
\hline Score 1 & confined hepatocytes' impairment on less than $25 \%$ \\
& area \\
Score 2 & confined hepatocytes' impairment on $25-50 \%$ area \\
Score 3 & extensive, rather localized hepatocytes' lesion \\
Score 4 & pervasive hepatocytes' necrosis \\
\hline
\end{tabular}

\section{Analytical Procedures}

Assessment of Hepatotoxicity and Hepatic Oxidative Stress: Alanine Transaminase (Reitman and Frankel, 1957), Aspartate Transaminase (Reitman and Frankel, 1957), Plasma Alkaline Phosphatase (Rec, 1972), and Serum Total Bilirubin (Jendrassik and Grof, 1938) levels were spectrophotometrically analyzed using commercially prepared kits from Randox Laboratories to assess liver damage. Catalase (Sinha, 1972), Superoxide dismutase (SOD) (Kono, 1978), Glutathione Reductase (GSH) (Carlberg and Mannervik et al, 1985) were also analyzed.

Results were represented as mean \pm standard deviation (SD). The experiment was laid out under completely randomized design. The data were analyzed by SPSS 16 version through one-way Analysis of Variance (ANOVA) to evaluate differences among treatments followed by the Least Significant Test (LSD) post hoc multiple comparison test at $\alpha \leq 0.05$.

\section{RESULTS AND DISCUSSION}

The functional importance of liver in xenobiotics' metabolism renders the hepatic tissues to be crucially vulnerable to the oxidative deterioration. $\mathrm{CCl}_{4}$ is a well-known hepatotoxic agent. In several studies, researchers have used $\mathrm{CCl}_{4}$ for developing in-vivo and invitro toxicity animal model owing to its hepatotoxicityproducing potential (Ogeturk et al., 2005; Jaramillo- 
Juarez et al., 2008; Khuon, 2012; Coballase-Urrutia et al., 2013; Salem et al., 2015). Thus, specific target of $\mathrm{CCl}_{4}$ administration appeared to be the hepatocytes, causing cellular necrotic alterations, fatty deterioration, fibrosis and cirrhosis.
The obtained liver weight and relative liver weight among the experimental groups is depicted in Table 1.

Table 1. Comparison among Body weight, Liver weight, and Relative liver weight of Control and different Experimental Groups of rats.

\begin{tabular}{|c|c|c|c|c|}
\hline & $\begin{array}{c}\text { Group I } \\
\text { (Control) }\end{array}$ & $\begin{array}{l}\text { Group II } \\
\left(\mathrm{CCl}_{4}{ }^{1}\right)\end{array}$ & $\begin{array}{c}\text { Group III } \\
\left(\mathrm{CCl}_{4}+\mathrm{QC}^{1,2}\right)\end{array}$ & $\begin{array}{c}\text { Group IV } \\
\left(Q^{1,2,3}\right)\end{array}$ \\
\hline Initial Body Weight (g) & $124 \pm 1.095$ & $181.5 \pm 23.132^{\mathrm{c}}$ & $169.83 \pm 16.91^{\mathrm{c}, \mathrm{n}}$ & $143.33 \pm 11.76^{\mathrm{n}, \mathrm{a}, \mathrm{a}}$ \\
\hline Final Body Weight (g) & $162 \pm 7.669$ & $209.5 \pm 23.67^{b}$ & $214 \pm 35.89^{\mathrm{b}, \mathrm{n}}$ & $177.3 \pm 22.54^{\mathrm{n}, \mathrm{n}, \mathrm{n}}$ \\
\hline Liver Weight (g) & $5.35 \pm 0.537$ & $7.92 \pm 1.312^{\mathrm{a}}$ & $4.9 \pm 0.2^{\mathrm{n}, \mathrm{a}}$ & $5.86 \pm 1.102^{\mathrm{n}, \mathrm{a}, \mathrm{n}}$ \\
\hline Relative Liver Weight & $2.619 \pm 0.323$ & $6.986 \pm 1.321^{\mathrm{b}}$ & $2.86 \pm 0.0173^{\mathrm{b}, \mathrm{a}}$ & $3.306 \pm 0.372^{\mathrm{n}, \mathrm{b}, \mathrm{n}}$ \\
\hline
\end{tabular}

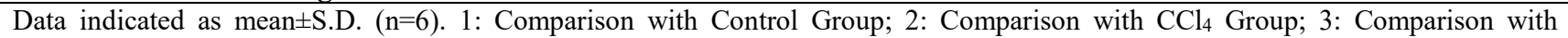
$\mathrm{CCl}_{4}+$ QC Group. a: $\mathrm{p} \leq 0.05 ; \mathrm{b}: \mathrm{p} \leq 0.01 ; \mathrm{c}: \mathrm{p} \leq 0.001 ; \mathrm{n}: \mathrm{p}>0.05$

$\mathrm{CCl}_{4}$ has shown significant alteration (augmentation) in the hepatic weight in comparison with the control group $(\mathrm{p} \leq 0.05)$ indicative of the hepatic injury leading towards fibrosis; whereas the $\mathrm{CCl}_{4}+\mathrm{QC}$ group had a significant reduction in the hepatic weight when compared with $\mathrm{CCl}_{4}$ group $(\mathrm{p} \leq 0.05)$ suggesting the reversal of the hepatic lesion towards alleviation of the disease-succession. The body weights, initial and final, were found to be increased among the experimental groups; however, the gain in weight was less and non- significant in the $\mathrm{CCl}_{4}$ group as compared with the control group and $\mathrm{CCl}_{4}+\mathrm{QC}$ group (Table 1).

Potential of QC on Modification of Plasma Enzyme Levels and Bilirubin: $\mathrm{CCl}_{4}$ induced hepatotoxicity was evidenced by the significant elevation in the plasma enzymes' concentration, ALT, ALP ( $\mathrm{p} \leq 0.001)$, AST $(\mathrm{p} \leq 0.05)$, and Bilirubin $(\mathrm{p} \leq 0.001)$ in $\mathrm{CCl}_{4}$-treated group as compared to the control group.

Table 2. Comparison among Various Plasma Enzymes and Bilirubin Concentration of Control and different Experimental Groups of rats.

\begin{tabular}{|c|c|c|c|c|}
\hline & $\begin{array}{c}\text { Group I } \\
\text { (Control) }\end{array}$ & Group II $\left(\mathrm{CCl}_{4}{ }^{1}\right)$ & Group III $\left(\mathrm{CCl}_{4}+\mathrm{QC}\right.$ & $\begin{array}{c}\text { Group IV } \\
\left(Q^{1,2,3}\right)\end{array}$ \\
\hline ALT (U/L) & $20.917 \pm 4.05$ & $32.36 \pm 4.52^{\mathrm{c}}$ & $25.78 \pm 3.59^{\mathrm{a}, \mathrm{b}}$ & $24.3 \pm 2.84^{\mathrm{n}, \mathrm{a}, \mathrm{n}}$ \\
\hline $\operatorname{AST}(\mathbf{U} / L)$ & $67 \pm 5.24$ & $88.4 \pm 6.98^{\mathrm{a}}$ & $42.33 \pm 12.48^{\mathrm{c}, \mathrm{c}}$ & $70.25 \pm 11.15^{\mathrm{n}, \mathrm{a}, \mathrm{c}}$ \\
\hline $\operatorname{ALP}(\mathbf{U} / \mathbf{L})$ & $96.45 \pm 7.49$ & $127.7 \pm 11.59^{c}$ & $115.27 \pm 6.62^{\mathrm{a}, \mathrm{n}}$ & $110.69 \pm 16.41^{\mathrm{a}, \mathrm{a}, \mathrm{n}}$ \\
\hline Bilirubin (mg/dl) & $0.69 \pm 0.06$ & $2.38 \pm 0.44^{\mathrm{c}}$ & $1.233 \pm 0.36^{\mathrm{b}, \mathrm{c}}$ & $0.922 \pm 0.2117^{\mathrm{n}, \mathrm{c}, \mathrm{n}}$ \\
\hline
\end{tabular}

Data indicated as mean \pm S.D. ( $\mathrm{n}=6)$ 1: Comparison with Control Group; 2: Comparison with $\mathrm{CCl}_{4}$ Group; 3: Comparison with $\mathrm{CCl}_{4}+\mathrm{QC}$ Group. a: $\mathrm{p} \leq 0.05 ; \mathrm{b}: \mathrm{p} \leq 0.01 ; \mathrm{c}: \mathrm{p} \leq 0.001 ; \mathrm{n}: \mathrm{p}>0.05$

Significant amelioration in ALT, AST and Bilirubin $(\mathrm{p} \leq 0.05,0.001,0.01)$ was unveiled in the $\mathrm{CCl}_{4}+$ Quercetin-treated group in comparison with the $\mathrm{CCl}_{4}$-treated group (Table 2). Significantly elevated levels of plasma enzymes were indicative of the hepatic damage produced by chronic $\mathrm{CCl}_{4}$ administration (Table 2). QC has shown to revert the deteriorative alterations of the liver parenchyma induced by $\mathrm{CCl}_{4}$, as indicated by the significant reduction of AST $(p \leq 0.001)$, ALT $(\mathrm{p} \leq 0.01)$, and Bilirubin $(\mathrm{p} \leq 0.001)$ levels in the $\mathrm{CCl}_{4}+\mathrm{QC}$ treated group in comparison with the $\mathrm{CCl}_{4}$ treated group (Table 2). Comparable findings were reported by Hassan and associates (Hassan et al., 2019), Kebieche and associates following the Epirubicin-induced acute liver injury (Kebieche et al., 2009), sodium fluoride (NaF)- induced deleteriousness of hepatocytes (Nabavi et al., 2012) and thioacetamide-induced hepatic necrosis (de David et al., 2011).

Potential of QC on Modification of Hepatic GSH, SOD and Catalase Activities: QC has shown to have strong antioxidant scavenging potential as reported by several studies (Hassan et al., 2019; Al-Harbi, 2019; Afifi et al., 2018).

GSH, SOD and Catalase provides the major mechanism of defense against hepatic oxidative damage. GSH possess lipid and hydrogen peroxide neutralizing capability, that chiefly contributes to its antioxidative potential (Han et al., 2006). In hepatocytes, abundance of GSH as a major reducing molecule also provides 
protection to the cellular proteins against oxidative damage. Proteins containing cysteine residue are especially vulnerable to redox modifications. Transformation of the cysteine's sulfhydryl form to thiolate form make it more sensitive against oxidative damage. GSH contributes in maintaining the redox state of the proteins' sulfhydryl groups (Yuan and Kaplowitz, 2009). In our study, significant reduction $(p \leq 0.001)$ in the activity of GSH was observed in $\mathrm{CCl}_{4}$ treated group in comparison to the control group. Significant elevation in the GSH enzyme activity $(\mathrm{p} \leq 0.05)$ was observed in the $\mathrm{QC}+\mathrm{CCl}_{4}$ treated group as compared to $\mathrm{CCl}_{4}$ treated group, suggesting its radical scavenging potential (Table 3). Comparable findings were reported by El-Sayed and associates following $\mathrm{CCl}_{4}$ mediated hepatotoxicity (ElSayed et al., 2015) and Afifi and associates after thioacetamide induced hepatotoxicity (Afifi et al., 2018).

Dismutation of superoxide anion into $\mathrm{H}_{2} \mathrm{O}_{2}$ is catalyzed by SOD; eventually, the biotransformation of $\mathrm{H}_{2} \mathrm{O}_{2}$ into water is done by GSH and Catalase. The interplay among SOD, Catalase and GSH causes the reduction of unstable radicals into water. In our study, significant curtailment $(\mathrm{p} \leq 0.05)$ was observed in the SOD activity in $\mathrm{CCl}_{4}$ treated group in comparison to the control group suggesting accumulation of superoxide anion in the hepatocytes. Significantly increased activity $(\mathrm{p} \leq 0.01)$ of SOD was observed in $\mathrm{CCl}_{4}+\mathrm{QC}$ group as compared to the $\mathrm{CCl}_{4}$ treated group that may be due to the improvement in the radical scavenging potential of SOD activity (Table $3)$.

Human catalase (hydroperoxidase) is a heme containing enzyme with NADPH being important cofactor for its activity. NADPH prevents catalase inactivation by $\mathrm{H}_{2} \mathrm{O}_{2}$. Abundantly found in the cells, this enzyme efficiently scavenges $\mathrm{H}_{2} \mathrm{O}_{2}$. Hepatocytes and erythrocytes possess the highest activity of Catalase (Young and Woodside, 2001). In our study, significant curtailment was observed in the Catalase enzyme levels $(\mathrm{p} \leq 0.01)$ in $\mathrm{CCl}_{4}$ treated group in comparison with the control suggesting catalase activity reduction that may be due to the reduced levels of NADP available to convert inactive catalase into active form. Treatment with $\mathrm{QC}$ and $\mathrm{CCl}_{4}$ provided significant elevation in the Catalase enzyme activity $(\mathrm{p} \leq 0.01)$ (Table 3$)$. Comparable results indicating protective effects of QC has previously been reported in several studies (Al-Harbi, 2019; Kebieche et al., 2009; Nabavi et al., 2012; de David et al., 2011).

Table 3. Comparison among Various Liver Antioxidant Enzymes and MDA activity of control and different Experimental Groups of rats".

\begin{tabular}{|c|c|c|c|c|}
\hline & $\begin{array}{c}\text { Group I } \\
\text { (Control) }\end{array}$ & $\begin{array}{c}\text { Group II } \\
\left(\mathrm{CCl}_{4}^{1}\right)\end{array}$ & $\begin{array}{c}\text { Group III } \\
\left(\mathrm{CCl}_{4}+\mathrm{QC}^{1,2}\right)\end{array}$ & $\begin{array}{c}\text { Group IV } \\
\left(Q^{1,2,3}\right) \\
\end{array}$ \\
\hline Catalase $(\mu \mathrm{mol} / \mathrm{g}$ tissue $)$ & $15.81 \pm 1.68$ & $3.331 \pm 0.18^{\mathrm{b}}$ & $12.932 \pm 9.1^{\mathrm{n}, \mathrm{b}}$ & $7.879 \pm 3.63^{\mathrm{a}, \mathrm{n}, \mathrm{n}}$ \\
\hline GSH (unit/g tissue) & $0.711 \pm 0.06$ & $0.02 \pm 0.0013^{\mathrm{c}}$ & $0.035 \pm 0.02^{\mathrm{n}, \mathrm{a}}$ & $0.03 \pm 0.004^{\mathrm{c}, \mathrm{n}, \mathrm{n}}$ \\
\hline SOD (unit /g tissue) & $1.036 \pm 0.593$ & $0.022 \pm 0.23^{\mathrm{a}}$ & $1.073 \pm 0.58^{\mathrm{n}, \mathrm{b}}$ & $0.819 \pm 0.31^{\mathrm{n}, \mathrm{b}, \mathrm{n}}$ \\
\hline MDA ( $\mu \mathrm{mol} / \mathrm{g}$ tissue) & $0.605 \pm 0.23$ & $1.4 \pm 0.65^{\mathrm{a}}$ & $1.04 \pm 0.17^{\mathrm{a}, \mathrm{a}}$ & $0.67 \pm 0.12^{\mathrm{n}, \mathrm{a}, \mathrm{n}}$ \\
\hline
\end{tabular}

Data indicated as mean \pm S.D. $(\mathrm{n}=6)$ 1: Comparison with Control Group; 2: Comparison with $\mathrm{CCl}_{4}$ Group; 3: Comparison with $\mathrm{CCl}_{4}+\mathrm{QC}$ Group. a: $\mathrm{p} \leq 0.05 ; \mathrm{b}: \mathrm{p} \leq 0.01 ; \mathrm{c}: \mathrm{p} \leq 0.001 ; \mathrm{n}: \mathrm{p}>0.05$

Effects of $\mathrm{CCl}_{4}$ and $\mathrm{QC}$ administration on Hepatic concentration of MDA: MDA, a major marker indicating lipid peroxidation which is the fundamental component of oxidative stress. The elevated levels of MDA in $\mathrm{CCl}_{4}$ treated rats were indicative of the oxidative damage produced to the liver cell membrane polyunsaturated fatty acids via CYP2E1-mediated activation of $\mathrm{CCl}_{4}$ and consequent transformation into tricholoromethyl and trichloromethyl peroxy radicals. The hepatic MDA concentration was significantly increased $(\mathrm{p} \leq 0.05)$ in $\mathrm{CCl}_{4}$ treated group as compared to the control group. In our study, $\mathrm{CCl}_{4}+\mathrm{QC}$ treated group showed significant reduction $(\mathrm{p} \leq 0.05)$ in the MDA levels as compared with the $\mathrm{CCl}_{4}$ group (Table 3). Our findings are consistent with that of other studies done to elucidate the effects of QC (Afifi et al., 2018; Al-Harbi, 2019;
Nabavi et al., 2012). Reversal of the initially $\mathrm{CCl}_{4}$ induced decreased antioxidant enzymes to near standard levels was observed in our study following QC administration (Table 3).

The histopathological findings in $\mathrm{CCl}_{4}$ treated rats included dilatation of the central vein, congested sinusoidal expansion with infiltration of the inflammatory cells suggesting peri-acinar necrotic alterations in hepatic tissues (Figure 1). Approximately 35 to $45 \%$ of decayed hepatic cells were seen. In comparison with the control group of rats, periportal- and portal fibrosis as well as inflammation along with portal lobulitis were evident in the $\mathrm{CCl}_{4}$ intoxicated group. QC treatment reduced the extent of the portal- as well as periportal fibrotic features from severe to mild form. Hepatocytic decay was absent in the QC treated rats. 


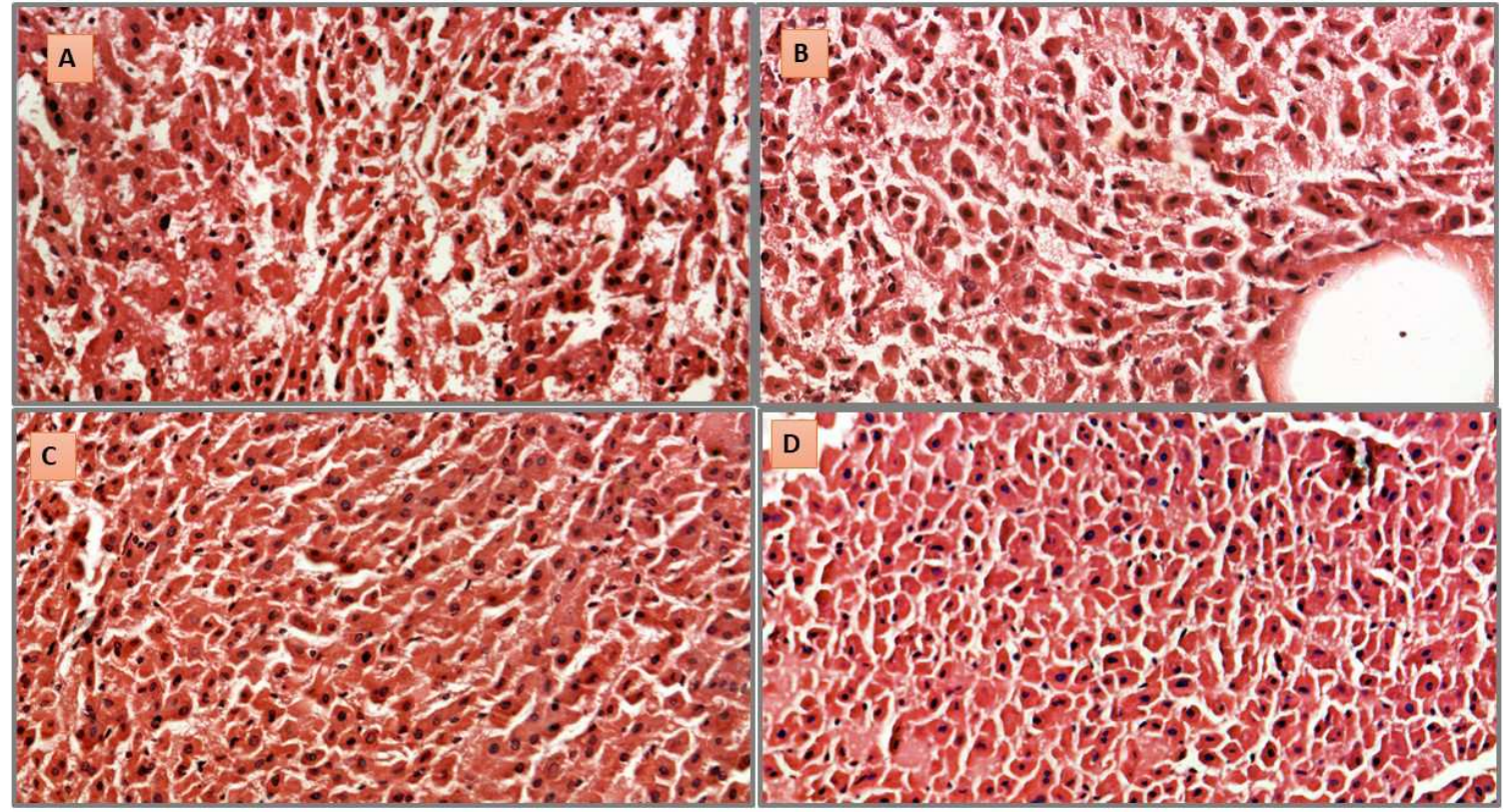

Figure 1: Photomicrographic representation of the hepatic centrilobular and periportal $\mathrm{H}$ and $\mathrm{E}$-stained sections depicting the effect of Quercetin administration on the $\mathbf{C C l}_{4}$ induced injury. A: Normal structural framework of the hepatocytes in control rats with mild sinusoidal fenestrations could be seen. $\mathrm{B} \mathrm{CCl}_{4}-$ intoxicated hepatocytes exhibiting dilated central vein, distended and congested sinusoidal-expansion with infiltration of the inflammatory cells suggesting periacinar necrosis. C: Restorative-potential of Quercetin in repairing the hepatic architecture close to the normal framework with organized hepatocytic strings; lacking the $\mathrm{CCl}_{4}$-induced necrotic alterations. D: Standard hepatic architectural framework in Quercetin treated group.

Conclusion: The deleterious effects produced by $\mathrm{CCl}_{4}$ exhibited by the observed fibrotic alterations of the hepatic parenchyma, elevation of plasma enzymes levels and the reduction in the hepatic-antioxidant enzymes, was shown to be significantly reverted attributed to QCadministration which suggests the potential protective role of $\mathrm{QC}$ against $\mathrm{CCl}_{4}$-induced hepatotoxicity.

Acknowledgements: We are thankful to the National Research Program for Universities-HEC (NRPU-6598) for funding the research.

\section{REFERENCES}

Afifi, N.A., M.A. Ibrahim and M.K. Galal (2018). Hepatoprotective influence of quercetin and ellagic acid on thioacetamide-induced hepatotoxicity in rats. Can. J. Physiol. Pharm. 96(6): 624-629.

Al-Harbi, M.S. (2019). Antioxidant, Protective Effect of Black Berry and Quercetin Against Hepatotoxicity Induced by Aluminum Chloride in Male Rats. Pharm. 15(4): 494-502.

Altuğ, T., S. Aydın, E.I. Taşkın, K.A. Dar, M. Caner, and A. Belce (2007). Protective effects of tomato consumption against the oxidative damage caused by $\mathrm{CCl}_{4}$ in rat's liver. Adv. Mol. Med. 3(4): 183-188.
Bedi, O., K.R.V. Bijjem, P. Kumar, and V. Gauttam (2016). Herbal Induced Hepatoprotection and Hepatotoxicity: A Critical Review. Indian. J. Physiol. Pharmacol. 60(1): 6-21.

Blachier, M., H. Leleu, M. Peck-Radosavljevic, D.C. Valla, and F. Roudot-Thoraval (2013). The burden of liver disease in Europe: a review of available epidemiological data. J. Hepatol. 58(3): 593-608.

Carlberg, I., and B. Mannervik (1985). Glutathione reductase. Methods. Enzymol. 113: 484-490.

Coballase-Urrutia, E., J. Pedraza-Chaverri, N. CárdenasRodríguez, B. Huerta-Gertrudis, M.E. GarcíaCruz, H. Montesinos-Correa, and J.J. EspinosaAguirre (2013). Acetonic and Methanolic Extracts of Heterotheca inuloides, and Quercetin, Decrease $\mathrm{CCl}_{4}$-Oxidative Stress in Several Rat Tissues. Evidence-Based Complementary Altern. Med. Article ID: 659165,13 pages.

de David, C., G. Rodrigues, S. Bona, L. Meurer, J. González-Gallego, M.J. Tuñón, and N.P. Marroni (2011). Role of quercetin in preventing thioacetamide-induced liver injury in rats. Toxicol. Pathol. 39(6): 949-957.

El-Sayed, Y. S., M.A. Lebda, M. Hassinin, and S.A. Neoman (2015). Chicory (Cichorium intybus L.) 
root extract regulates the oxidative status and antioxidant gene transcripts in $\mathrm{CCl}_{4}$-induced hepatotoxicity. PloS one. 10(3): e0121549e0121549.

doi: 10.1371/journal.pone.0121549.

French, S.W., K. Miyamoto, Y. Ohta, and Y. Geoffrion (1988). Pathogenesis of experimental alcoholic liver disease in the rat. Methods Achiev. Exp. Pathol. 13: 181-207.

Han, K.H., M. Sekikawa, K.I. Shimada, M. Hashimoto, N. Hashimoto, T. Noda, H. Tanaka, and M. Fukushima (2006). Anthocyanin-rich purple potato flake extract has antioxidant capacity and improves antioxidant potential in rats. Br. J. Nutr. 96(6): 1125-1134.

Hassan, A.M.S., F.I.A. El-Ela, and A.M. Abdel-Aziz (2019). Investigating the potential protective effects of natural product quercetin against imidacloprid-induced biochemical toxicity and DNA damage in adult rats. Toxicol. Rep. 6: 727735.

Hertog, M.G., P.C. Hollman, and B. Van de Putte (1993). Content of potentially anticarcinogenic flavonoids of tea infusions, wines, and fruit juices. J. Agr. Food Chem. 41(8): 1242-1246.

Jaramillo-Juarez, F., M.L. Rodriguez-Vazquez, A.R. Rincon-Sanchez, M. Consolacion, G.G. Martinez, J. Ortiz, and J.L. Reyes (2008). Caffeic acid phenethyl ester against carbon tetrachloride toxicity in rats. Ann. Hepatol. 7: 331-338.

Jendrassik, L., and P. Grof (1938). Quantitative determination of total and direct bilirubin in serum and plasma. Biochem. Z. 29: 81-89.

Kebieche, M., Z. Lakroun, M. Lahouel, J. Bouayed, Z. Meraihi and R. Soulimani (2009). Evaluation of epirubicin-induced acute oxidative stress toxicity in rat liver cells and mitochondria, and the prevention of toxicity through quercetin administration. Exp. Toxicol. Pathol. 61(2): 161167.

Kelly, G.S. (2011). Quercetin. Altern. Med. Rev. 16(2): 172-194.

Khuon, O.S. (2012). Role of Aqueous Extract of Apium graveolens Seeds Against the Haematotoxicity Induced by Carbon Tetrachloride in Female Rats. J. Col. Edu. Thi-Qar. University. Iraq. 2(6): 10-23.

Kono, Y. (1978). Generation of superoxide radical during autoxidation of hydroxylamine and an assay for superoxide dismutase. Arch. Biochem. Biophys. 186(1): 189-195.

Morales, J., G. Günther, A.L. Zanocco and E. Lemp (2012). Singlet oxygen reactions with flavonoids. A theoretical-experimental study. PLoS. One. 7(7): e40548.
Nabavi, S.M., S.F. Nabavi, S. Eslami and A.H. Moghaddam (2012). In vivo protective effects of quercetin against sodium fluoride-induced oxidative stress in the hepatic tissue. Food. Chem. 132(2): 931-935.

Nishimuro, H., H. Ohnishi, M. Sato, M. OhnishiKameyama, I. Matsunaga, S. Naito, K. Ippoushi, H. Oike, T. Nagata, H. Akasaka, S. Saitoh, K. Shimamoto, and M. Kobori (2015). Estimated Daily Intake and Seasonal Food Sources of Quercetin in Japan. Nutrients. 2345-2358.

Ogeturk, M., I. Kus, N. Colakoglu, I. Zararsiz, N. Ilhan and M. Sarsilmaz (2005). Caffeic acid phenethyl ester protects kidneys against carbon tetrachloride toxicity in rats. J. Ethnopharmacol. 97(2): 273-280.

Prior, R.L. (2003). Fruits and vegetables in the prevention of cellular oxidative damage. Am. J. Clin. Nutr. 78(3): 570S-578S.

Rec, G.S.C.C. (1972). Colorimetric method for serum alkaline phosphatase determination. J. Clin. Biochem. 10(20): 182-184.

Reitman, S., and S. Frankel (1957). A colorimetric method for the determination of serum glutamic oxalacetic and glutamic pyruvic transaminases. Am. J. Clin. Pathol. 28(1): 56-63.

Russo, G.L., M. Russo, C. Spagnuolo, I. Tedesco, S. Bilotto, R. Iannitti and R. Palumbo (2014). Quercetin: a pleiotropic kinase inhibitor against cancer. Adv. Nutr. Cancer. 159: 185-205. doi: https://doi.org/10.1007/978-3-642-380075_11.

Salem, M., H. El-Rasheid, and A. Mahmoud (2015). Therapeutic effects of curcumin and royal jelly as natural antioxidants on some biochemical parameters in hepatotoxicity induced by carbon tetrachloride $(\mathrm{CCl} 4)$ in male albino rats. IJAR. 3(11): 520-35.

Shin, H. S., J. H. Yoo, T. S. Min, K. Y. Lee and C. Y. Choi (2010). The effects of quercetin on physiological characteristics and oxidative stress resistance in olive flounder, Paralichthys olivaceus. Asian-Australasian. J. Anim. Sci. 23(5): 588-597.

Sinha, A.K. (1972). Colorimetric assay of catalase. Anal. Biochem. 47(2): 389-394.

Terao, J., Y. Kawai and K. Murota (2008). Vegetable flavonoids and cardiovascular disease. Asia. Pac. J. Clin. Nutr. 17(1): 291-293.

Umer, M., and M. Iqbal (2016). Hepatitis C virus prevalence and genotype distribution in Pakistan: Comprehensive review of recent data. World. J. Gastroenterol. 22(4): 1684-1700.

Uzun, F.G., F. Demir, S. Kalender, H. Bas, and Y. Kalender (2010). Protective effect of catechin and quercetin on chlorpyrifos-induced lung 
toxicity in male rats. Food Chem. Toxicol. 48(6): 1714-1720.

Velioglu, Y.S., and G. Mazza (1991). Characterization of flavonoids in petals of Rosa damascena by HPLC and spectral analysis. J. Agr. Food. Chem. 39(3): 463-467.

Young, I.S. and J.V. Woodside (2001). Antioxidant in health and disease. J. Clin. Pathol. 54(3): 176186.
Yuan, L., and N. Kaplowitz (2009). Glutathione in liver diseases and hepatotoxicity. Mol. Aspects. Med. 30(1-2): 29-41.

Zatoński, W.A., U. Sulkowska, M. Mańczuk, J. Rehm, P. Boffetta, A.B. Lowenfels and C. La Vecchia (2010). Liver cirrhosis mortality in Europe, with special attention to Central and Eastern Europe. Eur. Addict. Res. 16(4): 193-201. 